\title{
Austerity Beyond Crisis: Economists and the Institution of Austere Social Spending for At-Risk Children in Israel
}

\author{
ASA MARON \\ Department of Sociology, University of Haifa, Haifa, Israel \\ email: asamaron@soc.haifa.ac.il
}

\begin{abstract}
Austerity is frequently associated with crisis-enabled spending cuts. What happens when the crisis is over? This article's original contribution lies in its in-depth exploration of one mechanism that help explain austerity's endurance post-crisis, when state elites face increased popular resistance and pressure to reinstate social spending. This mechanism calls attention to the role of economists in Central Budgeting Offices as agents of technocratization and de-politicization within social policy domains. These economists may institute an austere spending mode by changing social spending's norms and instruments. To demonstrate economists' role in mediating macroeconomic fiscal goals and social policy design over time, the article examines the development of child welfare policy in Israel before, during and in the aftermath of economic crisis. In this case, austerity attained hegemony when economists were able to delegitimize and shelve an 'irresponsible' social spending proposal - and in response to post-crisis demands for compensation - introduce an austere policy instrument to cap social spending during a period of social policy expansion. This analysis suggests that scholars regard relations between austerity and social spending as dialectical.
\end{abstract}

Keywords: austerity; social policy; at-risk children; central budget office; economists; neoliberalism; retrenchment

\section{Introduction}

Austerity's implementation following the $2007 / 8$ global financial crisis revived scholarly interest in the ways economic crisis, macroeconomic policy and social policy may interrelate. Scholars frequently depict austerity as comprised of unpopular public-spending cuts implemented by state elites to reduce deficits and debt in the context of economic crisis (Clarke and Newman, 2012; Blyth, 2013; Farnsworth and Irving, 2015). However, this episodic view fails to account for austerity's relation with the broader neoliberal project of welfare state retrenchment. This lacuna raises questions regarding austerity's temporality and feasibility: is austerity indeed episodic? Does it only become feasible within conditions of economic crisis and emergency? If not, under what conditions can austerity possibly become entrenched? Austerity's outcomes trigger grievances 
and public pressure to reinstate social spending (Berglund, 2017; Standring, 2018; Papadopoulos and Roumpakis, 2018). In the face of such post-crisis pressure, how do states manage to maintain austere social spending?

This article contributes to addressing these questions by engaging in an in-depth exploration of one mechanism that may help to explain austerity's endurance post-crisis, during a time when economic emergency subsides and state elites face growing popular demand to reinstate social spending. This mechanism calls attention to the role economist-technocrats (hereafter, 'economists') in Central Budget Offices (CBOs) play as agents of technocratization and de-politicization within non-economic policy domains. Scholars have found increased involvement by $\mathrm{CBO}$ economists in social policy-making under neoliberalism (Asiskovitch, 2010; Cohen, 2013; Dahlström, 2009; Deakin and Parry, 2000; Marier, 2005). To understand their role in the state's resistance to social 'push back', this article offers a conceptualization of $\mathrm{CBO}$ economists as ideational entrepreneurs who establish novel institutions inside the state (Carstensen and Schmidt, 2016). CBO economists extend ideas and devices from the domain of macroeconomic policy to that of social policy. By establishing austere policy instruments capable of maintaining sway even during periods of social policy expansion, $\mathrm{CBO}$ economists may also succeed in transforming the norms and mechanisms of social spending.

To explore CBO economists' role in the endurance of austere social spending beyond economic crisis, the article examines the case of child welfare policy in Israel. The study follows the development of a single social policy before, during and in the aftermath of an economic crisis. This approach allows scrutiny of the dynamics of austerity over time, involving dialectical relations among crisisenabled social spending cuts, political response in the form of anti-austerity opposition, and policy response in the form of compensatory social policies - policies formulated to pacify anti-neoliberal opposition without jeopardising neoliberal tenets (Newman, 2003). In the early $2000 \mathrm{~s}$, Israel experienced severe economic crisis and emergency that led to the state's most radical period of neoliberal welfare state retrenchment. This retrenchment resulted in a reduction amounting to $3 \%$ of the GDP in overall expenditures for social services and benefits (Shalev et al., 2012). Among the groups who experienced the most severe impact were disadvantaged families with children. From 2000 to 2004 , child poverty rates rose from $25.2 \%$ to $33.2 \%$. The politicization of austerity's ramifications triggered a compensatory policy for at-risk children. The article explores CBO economists' central role in the adoption of an austere compensatory policy, which (unlike the alternatives) maintained the neoliberal goal of fiscal prudence via constrained social spending.

The article opens by discussing CBO economists and welfare state retrenchment strategies in neoliberal government. Following a section on case selection and methodology, it delves into the case of child welfare policy in Israel. It 
explores efforts to enact non-austere policy initiatives for at-risk children and the ways economists managed to de-legitimize and undermine them. The paper next traces economists' development of an alternative 'fiscally responsible' policy instrument, and its installation as the centrepiece of a new national policy launched in response to public outcry stemming from social spending cuts implemented following the $2001 / 2$ economic crisis. The final section concludes.

\section{Entrepreneurs of Austere Social Policy: CBO Economists and the Politics of Retrenchment}

Welfare state retrenchment is unpopular and generally difficult to inaugurate. Pierson (1994) identifies the politics of welfare state retrenchment as characterized by blame avoidance, whereby retrenchment's proponents - 'budget cutters' - act covertly to minimize opposition and electoral costs. Budget cutters can often reduce retrenchment's political cost when they are able to use economic emergency and crisis (e.g. mounting deficits) to frame, rationalize and justify austerity measures. Under the spectre of crisis, budget cutters may be able to advance radical welfare state reforms and dodge blame (Levy, 2010; Starke, 2006). However, during non-crisis periods, budget cutters must use stealthy strategies to meet their aims, including: obfuscating links between policy actions and outcomes, delaying retrenchment's consequences and distributing its impact (Pierson, 1994:19-26); utilizing hidden forms of retrenchment by 'delegitimizing and blocking compensatory interventions' in light of growing risks and diminishing effects of existing programs (Hacker, 2004:257); and adopting administrative measures for retrenching spending rather than revising formal policy (Bezes, 2007).

Yet, even when such strategies appear successful in the short-term, political opposition could still jeopardize retrenchment's achievements in the long run. Post-retrenchment demands for policy reversal and compensatory forms of social policy are inherent to the politics of neoliberal retrenchment (Levy, 2010:558; Newman, 2003). When the social consequences of retrenchment and austerity become publically evident, popular demands for compensation and reanimation of social spending typically follow (Berglund, 2017; Newman, 2003; Standring, 2018; Papadopoulos and Roumpakis, 2018). Austerity's endurance rests upon the state's approach to responding to such demands. For example, if the state responds by inaugurating costly compensation measures, cost-saving will decline and austerity will diminish (Levy, 2010:558).

The ways compensatory policies get formulated is an inseparable yet understudied aspect of social policy's relation to austerity in democratic settings. This article thereby focuses on CBO economists' role in designing post-retrenchment compensatory policy. The state has historically appointed $\mathrm{CBO}$ economists to devise and operate the state budget (Wanna et al., 2010). In recent decades, neoliberal governments have positioned $\mathrm{CBO}$ economists at the forefront of 
intra-state efforts to control and constrain public spending in the face of 'populist' demands for easement (Haffert and Mehrtens, 2015; Roberts, 2011: Chp.3; Schwartz, 1994; Wanna et al., 2010). Framing the conflict over spending as one arising between 'guardians' and 'spenders' inside the state (Wildavsky, 1993) helps to explain CBO economists' interest in limiting social spending, while other state units, primarily those responsible for welfare, education, and health, aim to increase it. Whereas the postwar era public consensus reduced frictions between guardians and spenders and provided conditions for increased social spending (Heclo and Wildavsky, 1974), the maturation of the welfare state, accompanied by growth in social spending, led CBO economists to develop a major concern to limit social expenditure.

Recent decades have witnessed the growth of economists' capacity to influence policy in government. Hirschman and Berman (2014) pose the question: "Do economists make policies?". In response, they identify three modes or sources of power through which economists influence policy. The first mode is professional authority: economists' ability to translate professional prestige and legitimacy into policy effects. The second mode is institutional positioning: economists' ability to acquire key positions in official policy organizations. The third power source reflects economists" ability to "reshape the cognitive infrastructure of policymaking" via either "spreading an economic style of reasoning ... or by helping to establish economic policy devices" (Hirschman and Berman, 2014: 790). CBO economists may draw on their professional authority and key positions in government to bolster their ideational power: a capacity to use ideas to redefine adequate spending in non-economic policy domains.

Whereas other studies have shown the ways economists use their professional skills and knowledge to influence social policymaking in neoliberalism (Asiskovitch, 2010; Cohen, 2013; Dahlström, 2009; Deakin and Parry, 2000; Marier, 2005), this article argues that CBO economists are additionally able to use ideas and ideational power to mould other actors' actions in social policy domains. Economists' ideational power lies in their ability 'to influence other actors' normative and cognitive beliefs through the use of ideational elements' (Carstensen and Schmidt, 2016:321). Ideational power may influence directly via persuasion or indirectly by effecting the ideational context from which actors draw inspiration (Hirschman and Berman, 2014: 790). It may range from the manipulation of general normative beliefs (such as aspired state-economy relations) to concrete cognitive ideas (e.g. efficacy of a policy program). By convincing others of their suggestions and assertions, economists may eventually be able to normalize new ideas such that they may be taken for granted (Schmidt, 2008).

CBO economists' capacity as ideational entrepreneurs draws on their knowledge and expertise. In addition to profound technocratic knowledge of public finance and the budgetary codex, economists may draw upon theoretical economic ideas (e.g. expansionary fiscal consolidation), economic concepts 
(e.g. utilitarian efficiency), and formulas (e.g. debt-to-GDP ratio). Based on these resources, $\mathrm{CBO}$ economists are able to issue factual economic statements. "Economic facts" form an important source of ideational power, which can be used to govern policy actors' beliefs and actions by constructing "some ways of acting as 'factually' possible and others as 'factually' impossible," toward advancing such goals as public spending cuts and budgetary stability (Eskelinen and Sorsa, 2013:5). The following section describes the method this study used to explore CBO economists' ability to use such ideas to effect an austere spending mode.

\section{Methodology}

\section{Case Selection}

To empirically explore the proposition that, as competent institutional entrepreneurs, $\mathrm{CBO}$ economists may establish austere modes of compensatory social spending, this article traces the development of a single social policy domain before, during and following an economic crisis. The case of child welfare policy in Israel during the years 1999 to 2010 was selected as an exploratory case for several reasons. First, effective institutions of fiscal consolidation developed in Israel earlier and were more successful than in most OECD states, who first encountered 'real austerity' following the 2007/8 financial crisis (Pierson, 2011:21). As such, Israel provides a rare long-term perspective on austerity's dynamics inside the state. Israel experienced significant economic crises in $1984 / 5$ and $2001 / 2$, which were followed by periods of extensive building of new fiscal institutions that subsequently led to social spending cutbacks (Ben-Bassat and Dahan, 2006; Mandelkern, 2015). The timeframe of this study (1999 to 2010) allows to follow economists' institution-building efforts in a single policy domain before, during and in the aftermath of the 2001/2 economic crisis. Figure 1 shows how economists acted during these episodes.

Second, Israel is a small and centralized state, and the Israeli CBO is a highly visible actor within government. The Israeli $\mathrm{CBO}$ is among the most centralized, hierarchic and influential budget offices in OECD countries (see below). As such, the case enables to gauge tendencies that are otherwise less available for empirical scrutiny, and explore the plausibility of an innovative theoretical proposition. Since the $1980 \mathrm{~s}$, in the context of prolonged political instability and a violent geopolitical conflict, the Israeli state nurtured a highly centralized, hierarchical and conservative Ministry of Finance (MoF). Unlike most OECD states, all fiscal affairs (budget, taxation, debt management), financial monitoring and accountancy functions are concentrated in a single office, providing its economists a broad mandate and room for action.

Compared with the OECD, the Israeli CBO - the Budgetary Division (BD hereafter) of the MoF - enjoys enormous influence over the budget. It is a highly 


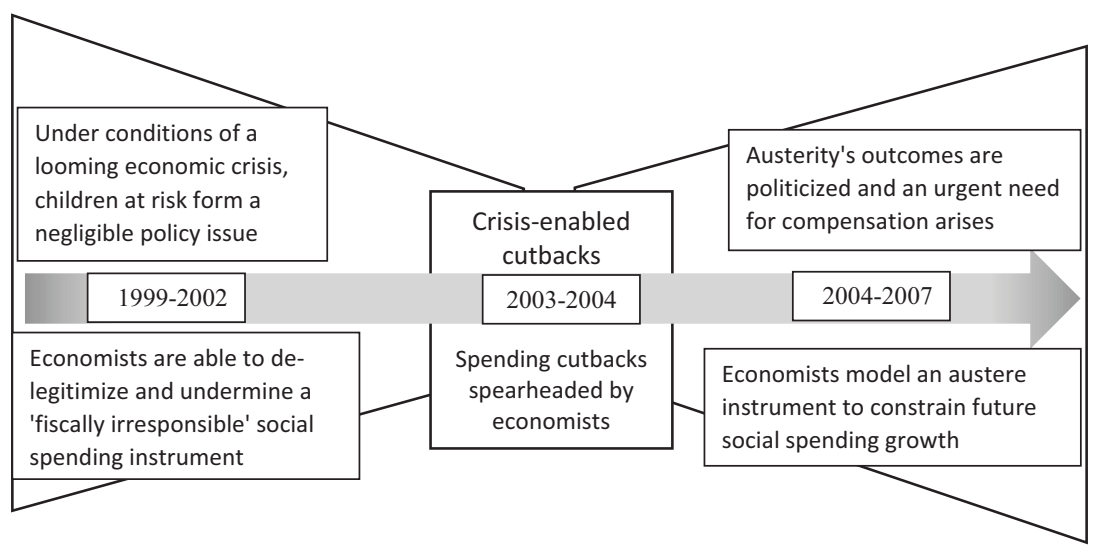

Figure 1. $\mathrm{CBO}$ economists' role in child welfare policy making before, during and following the economic crisis.

cohesive organization staffed by professional economists with neoclassic orientations and bachelor degrees acquired in research universities (Ben-Bassat and Dahan, 2006; Brender, 2009; Nachmias and Klein, 1999). Led by its CBO, Israel significantly reduced its public spending from $70 \%$ of GDP (1980) to become among the OECD lowest public (40\%) and social spenders (16\%) in 2017 (OECD Data, 2017). The Israeli CBO plays a dominant role in budget design and implementation (like in the UK); it enjoys both (1) a limited parliament authority to change the budget (like in the UK and Australia) and (2) the centralization of budget discussions in one parliamentary committee (like in Ireland and Finland) (Ben-Bassat and Dahan, 2006:29-68).

\section{Data Collection and Analysis}

Social spending for children is moulded within manifold policy arenas: from parliamentary discussions to the design and introduction of policy instruments. This article examines empirical evidence of processes that unfolded between 1999 and 2010 within distinct yet interconnected policy bodies, including Knesset (parliamentary) committees, public committees, and semi-public policy organizations. Connecting these arenas are economists' attempts to change the beliefs and actions of other actors engaged in designing social spending for children. Analysed materials include dozens of policy documents (see below) and 25 semi-structured interviews conducted between 2010 and 2015. Interviewed were 7 economists responsible for social budgets at the $\mathrm{BD} ; 8$ senior officials at the Child and Teen Unit at the Ministry of Welfare; and 10 senior employees of 2 non-governmental organizations highly involved in at-risk children policy (named Ashalim and JDC-Brookdale). All interviewees expressed 
their consent to participate in the research; the author explained the study's goals and subsequently shared findings with interested interviewees.

Policy documents include official publications attained via the Israel State Archive and the Knesset Archive and website (including committee reports and full session minutes) and unofficial documents from the collections of Ashalim and JDC-Brookdale (including documentation of policy experiments and protocols). Interviews were transcribed and analysed alongside the documents to illuminate actors' ideas and convictions. Meticulous analysis of the written materials focused on economists' argumentations and actions vis-à-vis those of politicians and 'spending' bureaucrats. It also involved sequencing of policy events, juxtaposing alternative policy outcomes and examining discursive interactions and coordination among policy actors. Due to the limited scope of the article, only a handful of representative excerpts are embedded in the text.

\section{Approaching the Crisis: Policy Initiatives Aimed at Meeting the Needs of Children at Risk}

The social problem of at-risk children developed during the $1990 \mathrm{~s}$ as a result of increased attention to child abuse and neglect, and in the context of a widening gap between needs and policy responses. This period saw the retrenchment of Israel's two most important public programs for combatting child poverty - Child and Social Security Allowances (Gal and Ben-Arie, 1999) - and rising poverty rates among families with children (see figure 2). At-risk children are defined as children with special conditions and needs, including delayed development, behavioural problems, and/or experiences of neglect or abuse. The majority of at-risk children live in economically impoverished families.

Agenda-setting and policymaking addressing at-risk children between 1998 and 2003 took place under the spectre of a looming economic crisis. Beginning in 1996, Israel's economy entered a deep recession, manifested in decreasing revenues, mounting deficits, and growing unemployment, reaching bottom in the early $2000 \mathrm{~s}$. Several legislative initiatives were advanced to secure the social rights of children at risk during this period. The Infants at Risk Act (2000), the Rights of Children at Risk for Services Bill (2000) (henceforth, the Rights Bill), and the endeavour to amend the 'Youth Act' (Service and Care; Out-of-Home Services for Disadvantaged Children) (2001) were all attempts to institute a legal obligation to earmark budgets fulfilling the rights of at-risk infants, children and teens to receive services as delineated by local welfare authorities. However, these initiatives were either blocked or constrained. In order to show how economists portrayed the legislation of social rights as fiscally irresponsible, and convinced the government to oppose legislation, I here focus on the Rights Bill, the most comprehensive of the three legislative proposals. 
Children in Poverty in Israel (percent), 1990-2010

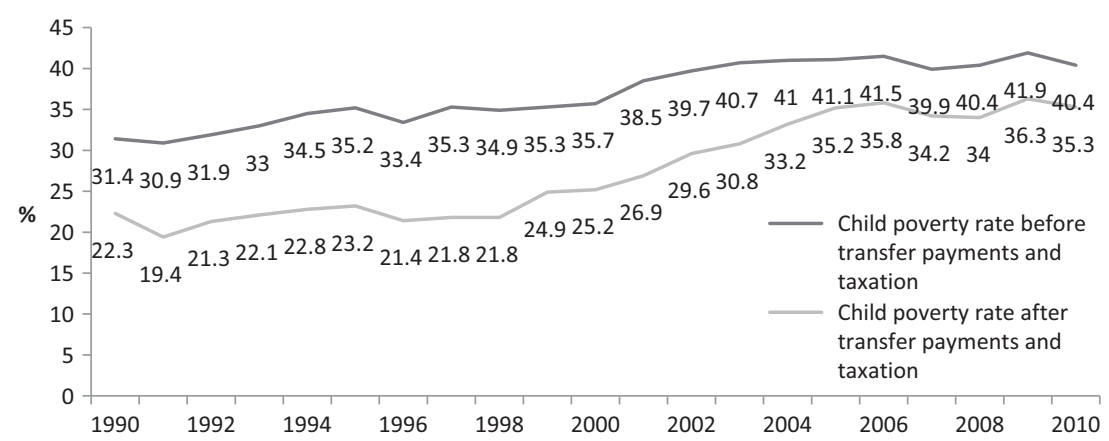

Figure 2. Children in Poverty in Israel, 1990-2010 (Source: Annual Review of the National Insurance Institution, various years).

The Rights Bill comprised a comprehensive policy response in that it established a new social entitlement for children and teens defined as being at risk. The Ministry of Welfare (MoW) drafted the bill and presented it at the Knesset Child Wellbeing Committee (later renamed Children's Rights Committee; hereafter CRC) in May 200o. The CRC's chair promoted the bill, which received wide support in the Knesset (Knesset CRC June 21, 2000, Protocol no. 52). By rallying political support, the bill's advocates aspired to pressure the $\mathrm{BD}$, to overcome its previous veto to allotting additional budgetary resources to child welfare services (Senior Official, Ministry of Finance, 8.12.2010; Senior Official, Ministry of Welfare, 7.1.2010; Knesset CRC Chair, 30.11.2014).

The Rights Bill proposed a new policy instrument that authorized local professional eligibility committees with the capacity to endow individual children with new social rights based on bureaucratic and professional logics (Clarke and Newman, 1997). This policy instrument marked a significant development in securing the state's responsibility for children at risk: its passage compelling legal recognition of children's needs and adequate budget allocations to address them (previously, local welfare agencies received capped funds unmatched to local needs, and local government was required to cover $25 \%$ of costs). This policy instrument authorized senior social workers to make sovereign decisions carrying binding budgetary consequences, thus undermining the BD's capacity to control aggregate spending. Consequentially, the proposed policy instrument's capacity to ensure a fiscally responsible policy received centre stage.

The bill provided for local welfare offices (in which MoW's social workers operate under municipal governments) to operate eligibility committees for evaluation and determination of troubled children's levels of eligibility for services according to risk indicators listed in the bill. The eligibility committee's 
protocol was to name specific risk events, harmful conditions, and undesired outcomes ranging from outright abuse to neglect to a lack of adequate family resources, all of which may be disturbing the child's normative development. Valid for one year following evaluation, an eligibility evaluation classified a child as falling within one or more of four categories of risk and three categories of harm. The Rights Bill also designated eligibility committees as responsible for compiling individual treatment plans. Different eligibility levels were to confer different amounts of public funds per child (between $\$ 2000$ and \$30,000 per annum), to be managed at the discretion of local welfare offices. The government was to be required to fund every eligible child (for an estimated 200,000 eligible children). These resources were to be bureaucratically assigned per eligible child and accordingly distributed to local welfare agencies responsible for implementing the individual treatment plans. To conclude, by giving street-level bureaucrats (social workers on the eligibility committees) professional discretion bearing budgetary repercussions, the Rights Bill policy instrument subordinated budgetary goals (e.g. keeping a balanced budget) to social goals (providing entitlement to social services).

\section{De-Legitimization of a 'Fiscally Irresponsible' Mode of Social Spending}

The Rights Bill's policy instrument met with sharp criticism, from the BD of the MoF first and foremost. Since the proposed instrument would have undermined the BD's capacity to control social spending, the $\mathrm{BD}$ argued that the instrument was fiscally irresponsible. During the bill's Knesset debate, the BD welfare attaché explained his office's objection:

First, while the bill attempts to confine future budgetary costs ... we are concerned that the budget framework will be breached, since the bill dictates funding per risk level, so the level of risk will ultimately determine its costs.... Second, we believe making all services equally available ... will prevent a genuine consideration of cost-benefits .... By setting no budgetary constraints and limits on administrative action, this legislation would without a doubt cost several billion ILS [hundreds of millions of US\$] .... (Protocol 47 of the CRC, 30 May 2000, the 15th Knesset)

This excerpt illuminates some of the ways this legislation could have impaired the BD's control by shifting budgetary discretion to "unchecked spenders". During interviews, BD economists explained that authorizing entitlement would have permitted spenders to determine the scope of social spending, raise expenditures, and undermine mechanisms of spending control (Senior Official, Ministry of Finance, 8.11.10; Senior Official, Ministry of Finance, 8.12.2010). Guaranteed-by-law social eligibilities and the bureaucratic-professional instruments empowered to produce them threatened the BD's control over spending by potentially enabling other actors to make consequential 
decisions, thereby engendering what Wildavsky terms a "tyranny of entitlement" and the creation of "rigid", long-term budgetary commitments (1993: 268).

In light of this critique, the CRC ordered a policy experiment to test the bill's applicability and expected costs. An applied research institute, working closely with the MoF and the MoW, was contracted to administer and evaluate the experiment, following which it articulated a second line of critique (Preliminary Experiment to Test the Rights of Children at Risk for Services Bill. Unpublished Draft. Brookdale-JDC, June, 2001). It argued that the proposed instrument would provide senior social workers misguided incentives that would encouraging irresponsible spending. Following this experiment, conducted in 2002, a senior researcher reported back to the CRC:

Except for the good will of professionals ... this bill lacks any incentive for making services more efficient .... It has no outcome-oriented incentives .... Social workers will "fall asleep, go numb" and the only one to be harmed as a result will be the child, since local budgets would only increase.... Children's risks can escalate as a result of their not being treated, and, as a result, incoming budgets will only grow.... There is no incentive to use resources efficiently.... If there is a child who needs more than he is receiving at the moment, the only thing to do is wait for his condition to worsen. If there is a child who receives more than he needs, the only thing to do is to find how to spend it at all costs. There is no way to control spending in this model.... (Unnumbered Protocol, discussion at the CRC on 15 July 2002).

Positioning "budget protection" as a meta-goal, the argument expressed above uses economic reasoning (Hirschman and Berman, 2014: 794) to depict social workers as self-interested agents, who would undertreat children in order to maintain their poor condition and the concomitant flow of incoming funds, since children no longer "at risk" would lose eligibility and the monetary allotment their needs would sustain. Economic reasoning here aims at delegitimizing professional discretion when carrying budgetary consequences.

The same research institute restructured the proposed policy instrument in ways that removed "squandering incentives" and submitted it to the CRC for consideration (Proposal for additional Changes in the Rights of Children at Risk for Services Bill. Unpublished Draft. Brookdale-JDC, July 11, 2002). In the revised instrument, social workers would continue to determine individual levels of eligibility, yet without being guaranteed entitlement to funding. This purposed model of "quasi-eligibility" was justified by again invoking budgetary interests:

Clearly, we do not attempt to serve all needs, yet we all share some responsibility here. We want to have the best possible outcome, while keeping some budget aside for other matters the State of Israel would like to budget.... We live in a world of finite resources... [but] we can use given resources more efficiently. We cannot meet all needs with services. There will always be a mismatch, although we attempt to reduce it as much as possible, in the most efficient way.... (Unnumbered Protocol, discussion at the CRC 15 July 2002) 
Economists play a central role in de-politicizing and normalizing the permanent state of resource scarcity in neoliberalism. The BD's power to practice effective macro-level budgetary control and establish budgetary discipline translates into an economically cognizant "cognitive infrastructure of policymaking" (Hirschman and Berman, 2014: 794) that obfuscates the practice of budget discipline. In the CRC's final discussion of the bill (following rejection of the revised bill), the BD welfare attaché used his office's authority to speak on behalf of the government:

The MoF objects in principle to legislation that would dictate priorities within the Ministry of Welfare and generally within government, as it damages the flexibility of the Ministry.... No one says it is unimportant. The question remains as to how to manage it. The government objects to the bill.... (Unnumbered Protocol, discussion at the CRC 15 July 2002)

By the end of 2002, within the contexts of an emerging economic crisis, the government's anticipated disbanding, and the imposition of crisis-enabled cutbacks, the Rights Bill was dropped from the CRC's agenda. Two related bills under consideration experienced similar outcomes. The Infants at Risk Act aimed to establish the state's responsibility to place every eligible at-risk infant in special day care services. Although the Infants at Risk bill was enacted in 2000, fierce struggles with the opposing BD led eligibility provisions to be narrowed and restricted, and its implementation was delayed until 2008 (Knesset CRC, 15.10.2001, Protocol 106). Amendment to The Youth Act (Service and Care) was advanced to establish the state's responsibility to place at-risk children and teens in dormitory out-of-home services when advised by authorized social workers. However, following fierce resistance of the BD, the Youth Act was eventually dropped, renegotiated and finally replaced to include a capped non-legal spending arrangement (Knesset Labor, Welfare and Health Committee, 27.2.2008, Protocol 390).

\section{Proactive Guardians: Compensating for Cutbacks via 'Responsible' Social Spending}

Led by the MoF, the government reacted to the burgeoning economic crisis by enacting emergency legislation to impose radical "crisis-enabled" austerity cutbacks. Welfare cutbacks in 2003 decreased incomes for families dependent on child allowances and social security allowances. Consequently, more than 33,000 families and 131,000 children newly fell below the poverty line (National Insurance Institute, 2003). In 2004, a second emergency program generated budget cuts to line ministries' budgets for the years 2005-2010, and introduced a fiscal rule to constrain the annual growth of public spending to a percentage of GDP, providing economists another form of budget containment leverage to control aggregate spending (Brender, 2009: 14). 
The crisis-spawned austerity cutbacks of 2003-2004 led to dramatic changes in children's social welfare needs. From 2000 to 2003, the number of children living in poverty grew by $36 \%$, children treated by welfare services grew by $37 \%$, and children with juvenile criminal records grew by $26.5 \%$. Austerity's farreaching repercussions fomented political unrest demanding compensation for social insecurity in the form of renewed spending on children and teens at risk (Evaluating the Conditions of Children and Teens at Risk and Distress, 2006: 62). Within the framework of the CRC, politicians held intense discussions with senior bureaucrats from the Welfare, Health, and Education Ministries, advocacy groups and representatives of at-risk children and parents, all of whom emphasised the cutbacks' detrimental social outcomes (Knesset CRC, May 12, 2003 Protocol 1; Knesset CRC, July 30, 2003, Protocol 17). The incoming Minister of Welfare presented the matter as an urgent problem and insisted that the Prime Minister (heading a coalition government) establish a national evaluation committee to examine it and propose solutions (Knesset CRC, July 30, 2003, Protocol 17).

While economists have demonstrated their ability to circumvent some initiatives to expand social policy, blocking budget allocation for popular initiatives addressing politically salient policy problems has sometimes proven harder to accomplish. Under such circumstances, CBO economists may opt to undertake less visible actions to constrain spending growth, to promote austerity by stealth by designing fiscally responsible policy instruments for constraining welfare state expansion. CBO economists - who deeply opposed legally-binding social entitlements that undermine their control of the budget - were pivotal in promoting an alternative policy instrument. In the context of the de-legitimized and abandoned Rights Bill in question, and the imposition of crisis-enabled austerity cutbacks in 2003-2004, an austere policy instrument to address children's needs was designed, based on constraining local welfare bureaus' spending.

\section{Experimenting with Fiscally-Responsible Policy Instruments}

The previous section shows economists' ability to convince other actors that some policy programs are infeasible or counterproductive. This section focuses on their ability to offer adequate policy alternatives, which is central to their capacity as institutional entrepreneurs of austerity. In the midst of the austerity cutbacks, two policy programs (Community 2000 and Toward the Community) were inaugurated, in 2003 and 2004 respectively, in order to experiment with new policy instruments for governing the risks of children and families without breaching social expenditure limits. These initiatives provided the BD with an opportunity to shift away from dormitory, out-of-home services toward costefficient, inexpensive and flexible community-based services, while maintaining direct control to avert double spending (erroneously paying for both 'old' and 'new' services) (Senior Official, Ministry of Finance, 8.12.2010; Senior Official, 
Ministry of Welfare, 7.1.2010). The implementation of a fiscally sound policy instrument, delegation of budgetary discretion to local welfare offices, and enabling experiment with cheaper, more cost-effective community services all reinforced local welfare offices' responsibility. The $\mathrm{BD}$ intended this move to encourage peripheral state agencies to "cater to more needs for less," while maintaining the imperative of budget non-growth. This initiative received further inspiration from the de-institutionalization trend and professional shift within MoW and Ashalim toward community-based social services for at-risk populations.

The Local Action Model (hereafter Action Model) was the name of the policy instrument that had developed out of experimentation with cost-effective administrative routines. It aimed to develop local welfare offices' managerial capacities in ways that would curb irresponsible budget inclinations via new forms of surveillance and control (see Hoggett, 1996; Newman, 2001). The earlier critique and counter-proposals to the Rights Bill's "squandering model" provided the new policy instrument with a blueprint for controlling local administrative practices. The Action Model structured organizational procedures with the goal of meeting children's needs at low cost by designing sets of cost-effective community services matching local "risk profiles" (Ministry of Welfare and Brookdale-JDC, 2007: 6-10, 20-30). The new delegation of authority and responsibility to the local level that Action Model provided coincided with new forms of increased control from above. Action Model became formalized to enforce the use of policy techniques that produce efficient budgetary planning and execution. Such techniques function as a "technology of performance" (Dean, 2010: 197-198), subordinating local state agents and agencies to a set of performance measures that inculcate "calculative agency".

Experimentation with Action Model yielded mixed outcomes (see Ashalim, the Ministry of Welfare, and Brookdale-JDC, 2007; Ministry of Welfare and Brookdale-JDC, 2007), yet its architects deemed the efforts it guided successful in reconstituting welfare bureaus as responsible, self-governed agencies. According to various policy reports, the authority to plan, budget and develop services was effectively transferred from central to local government, inculcating an efficient local mode of responsibly managing limited resources. Economized policy instruments can facilitate certain ways of seeing, formalizing, quantifying and acting upon social problems (Hirschman and Berman, 2014: 796-800). Action Model thus constituted an effective austerity-inspired policy instrument, developed to govern local agencies by increasing their calculative capacities in order to optimize their use of limited resources.

\section{Constraining Social Spending with an Austerity Policy Instrument}

The demand to compensate impoverished children for austerity's effects was met in 2008. The Public Committee for Evaluating the Conditions of 
Children and Teens at Risk and Distress (also named the Schmid Committee after its chair, hereafter Schmid Committee) submitted its recommendations in March 2006, which the government embraced in August 2007 (Government Decision No. 2281). In 2008, the Prime Minister's office initiated the "National Program for Children at Risk". The national program was implemented in 56 municipalities (later expanded to 170) with the lowest socio-economic rankings in the country, with particular emphasis on locales with a high percentage of Arab, immigrant and ultra-Orthodox Jewish children, considered the populations with the greatest likelihood of risk (Dolev, 2009: 189).

The Action Model policy instrument became the centrepiece of the national program. Action Model was developed to encourage fiscally prudent and responsible local management of welfare agencies through austere organizational routines. Just as BD economists had been central in defining the program's governance and budgeting, they also played a major role in its implementation (Senior Official, the National Program for At Children, 22.1.2015). In line with the BD view, the Schmid committee had recommended refraining from abiding by earlier legislation and abolished professional eligibility committees, the policy instrument that had threatened fiscal control in the Rights Bill (Senior Researcher, Brookdale Institute, 21.10.2010; Evaluating the Conditions of Children and Teens at Risk and Distress, 2006). The committee instead upheld Action Model as a policy instrument well suited to make welfare agencies fiscally responsible, as it enabled them to address children's needs cost-effectively and efficiently.

Compared with the spending model of the Rights Bill (2000), the new policy instrument disconnected local risk levels from budgets allocated to the local level. Under the Rights Bill, the overall budget had been determined from the bottom up (based on professionally diagnosed risks and defined entitlements). Here, the overall budget was determined from the top down, a lump sum arrived at through a preliminary compromise between the MoF and the MoW. Set at roughly 40 million USD per annum, to be allocated among local welfare offices according to a formula taking into account the total population size, child population, and overall socio-economic status of the locale. The national program contained spending by designating pre-determined budgetary limits without considering actual levels of diagnosed needs.

Action Model signalled a shift towards local self-governance regarding service design and implementation with increased centralized control and supervision of budgeting, a form of "centralized decentralization" (Hogget, 1996). A new independent agency was formed to supervise Action Model's local implementation, oversee goal attainment and maintain agreements between the central and local governments (National Program for Treating Children and Teens at Risk and Distress, 2007: 16). The agency's most important task was to allocate budgets directly to the designated municipalities. A senior official explained how the agency gained the BD's trust by turning itself into a 
"mini-budget division for children-at-risk" (Senior Official, the National Program for At Risk Children, 22.1.2015). At the local level, municipal welfare offices were to follow structured procedures to select and budget new costefficient community services to optimize the number of service units and minimize costs (Brookdale-JDC, 2009). Unlike the Rights Bill, the Action Model was not based on individual entitlement and suffered from a mismatch between resources and needs. Without eligibility, only a small fraction of the at-risk population receives services. The Action Model's fragility from a citizenship standpoint was reflected in the program's low level of service reception: of the 156,000 children the program identified as being at risk, only $33 \%$ received services in 2011 (State Comptroller, Annual Report, 62b 2011: 871). In late 2014, the program provided services to only some 40,000 children, which amounted to $26 \%$ of the documented population in need (National Program $\left(360^{\circ}\right.$ ) for Children and Teens at Risk, 2015: 16).

In sum, $\mathrm{BD}$ economists played a central role in the design of austere policy for at-risk children (Senior Official, Ministry of Finance, 23.5.2011). Following repercussions from crisis-enabled cutbacks, the PM inaugurated a new national program for at-risk children, yet economists dominated the process of designing and budgeting it. They introduced Action Model as an austerity-inspired policy instrument that could translate the ambiguous notion of fiscal responsibility policy to the mundane practices of local welfare offices. The Action Model instrument was lauded for providing control of unchecked spending, modelling organizational routines, and maximizing the production of service units, in contrast with the previous model that would have granted potential recipients legally binding eligibility for social services.

\section{Conclusions}

This paper demonstrates the value of exploring the austerity-social policy nexus over time periods extending beyond immediate crises, studying relations between short episodes of crisis-enabled social spending cuts and longer episodes, during which states react to political backlash triggered by retrenchment. This paper suggests viewing relations between austerity and social spending as dialectical: as political moments, economic crises enable state elites to implement cutbacks and increase control over social spending. However, when economic emergency subsides, austerity's social outcomes can trigger political grievance, leading to public pressure to reinstate social spending. As governments face resistance and renewed demands for de-commodification and compensation in between crises, the maintenance of austerity over time depends to a large extent on the ways states react to such political pressure. This article explains austerity's endurance by focusing on CBO economists' role as "proactive guardians" who succeed in disciplining renewed demands for compensatory social policy. This stealthy 
strategy maintains austerity beyond crisis by constraining social spending during periods of social policy expansion in neoliberalism.

The analysis of the case of child welfare policy in Israel demonstrates the centrality of $\mathrm{CBO}$ economists in the maintenance of austerity (see Figure 1). Such a scenario is more likely to happen in centralized, professionalized and conservative $\mathrm{CBOs}$ that develop a cohesive and consistent understanding of their role in neoliberal government. When increased child poverty (the result of crisis-enabled cutbacks) triggered public grievance and supported a political demand for compensation, $\mathrm{CBO}$ economists dominated the state's response by designing an austere policy instrument in line with their imperative of fiscal responsibility via constrained spending. CBO economists' capacity to delegitimize uncapped social spending proposals and introduce austere social spending routines draws primarily on their ideational power, especially their ability to manipulate other state actors' beliefs and redefine the ideational context in which other policy actors operate. Ideational power serves to establish, de-politicize, and naturalize economic scarcity as a factual, permanent condition. It redefines the realm of the 'politically plausible', which in turn curbs social spenders' expectancies within social politics and policymaking.

Research shows that legally binding social entitlements are more resilient to austerity cutbacks in comparison to 'soft' discretionary spending on social services and investment (Breunig and Busemeyer, 2012; Pierson, 1994; Haffert and Mehrtens, 2015). This article reveals the ways social policy's fiscal consequences motivate $\mathrm{CBO}$ economists. They anticipate the development of rigid forms of social spending - which may undermine future retrenchment efforts - and strive to replace them with flexible forms that can be adjusted when fiscal circumstances change. The institution of austere, flexible forms of social spending is thus one of the stealthy mechanisms through which welfare state retrenchment and austerity can be realized (Starke, 2006: 115-116). This article argues that CBO economists are central to such austerity processes as they advocate forms of spending that do not incorporate feedback effects, thereby reducing social programs' path dependency and making the welfare state less resilient and easier to retrench (Pierson, 1994).

For CBO economists, the Marshallian logic of social rights of citizenship is unwanted as it leads to the "tyranny of entitlement" (Wildavsky, 1993: 268). In their capacity as institutional entrepreneurs of austere social spending, CBO economists formulate an alternative policy instrument and establish a mode of social provisioning based on the logic of "provisional utilitarianism". Economists achieved what appeared as a rational and efficient attempt to maximize the number of children who could benefit from the national program's capped budget. Following prescribed procedures, local welfare authorities' evaluate children risks and form aggregate local risk profiles. Based on such profiles, targeted services are established at the local level. This achieves an 
effective and utilitarian mode of provisioning that do not create a state commitment to guaranteed individual entitlement. The national program's fixed and capped annual budget is unable to meet the needs of all diagnosed children and teens. By combining an annual spending cap with a comprehensive model of provisional utilitarianism, economists' social policy design was a coordinated political effort aimed at de-politicizing and legitimizing a restrained policy response to growing social insecurity. Once established, an austere mode of social spending instils an economically driven approach to addressing and managing social problems, upending previous policy logics based on bureaucratic routines and professional discretion. This dynamic renders unfeasible the Marshallian ideal of guaranteed individual entitlement to social rights of citizenship.

Recent research shows austerity does not manifest in a full scale withdraw of social services and entitlements. Instead, austerity advances services' reorganization aimed at meeting the imperative of restrained spending by reducing services' quality and availability. Reduction of availability occurs via increased eligibility thresholds, defunding of service providers, withering of user subsidies, placing greater emphasis on conditionality, and shifting from universalism to selectivity and needs-based eligibility (Brimblecombe et al., 2018; Cox, 1998; Harlock et al., 2018; Lewis and West, 2017; Morris, 2019). Authors also argue that austerity increases decentralization and local administrators' discretion to undermine the legal, certain status of social rights. Austerity's imperatives thus become delegated to local decision making, by coercing administrators to decide how to distribute scarce public resources in the absence of proper guidelines (Cox 1998; Harlock et al., 2018).

The article contributes to the literature on changes to social provisioning under austerity, demonstrating how austerity may also decrease local discretion by subjecting local administrators' discretion to centrally designed prescriptions (based on austere spending routines), thus turning them into efficient governors of aggregate local risks. Some argue that austerity manifests itself via a moral discourse of reciprocity, fairness and welfare abuse to emphasize conditionality and discipline in social provisioning (Morris 2019). In contrast, this article delineates the ways austerity may become manifest via 'value free' administrative prescriptions to affect provisioning for morally deserving groups and undermine their social citizenship.

\section{Acknowledgements}

The author would like to thank Michael Shalev, Sara Helman, Rebecca Elliott, Ronen Mandelkern, Yuval Yonay and Tami Oren for their valuable comments on earlier drafts. 


\section{References}

Ashalim, the Ministry of Welfare, and Brookdale-JDC (2007), Community 2000 - Project Book, Jerusalem.

Asiskovitch, S. (2010), 'Bureaucratic Actors in Mature Welfare Atates: The Case of Israel', Policy \& Politics, 38, 4, 547-563.

Ben-Bassat, A. and Dahan, M. (2006), The Balance of Power in the Budgeting Process. The Israeli Democracy Institute, Jerusalem.

Berglund, O. (2017), 'Contesting Actually Existing Austerity', New Political Economy, 23, 6, $804-818$.

Bezes, P. (2007), 'The hidden politics of administrative reform: Cutting French civil service wages with a low-profile instrument', Governance, 20, 1, 23-56.

Blyth, M. (2013), Austerity: the history of a dangerous idea. New-York, Oxford University Press.

Brender, A. (2009), 'Targets or Measures? The Role of the Deficit and Expenditure Targets in Israel's Fiscal Consolidation Efforts, 1985-2007', The Israeli Tax and Economics Quarterly, 33, 129, 7-33.

Breunig, C. and Busemeyer, M.R. (2012), 'Fiscal austerity and the trade-off between public investment and social spending', Journal of European Public Policy, 19, 6, 921-938.

Brimblecombe, N., Pickard, L., King, D. and Knapp, M. (2018), 'Barriers to receipt of social care services for working carers and the people they care for in times of austerity', Journal of social policy, 47, 2, 215-233.

Brookdale-JDC (2009), Community Services Comprehensive Planning Manual. The National Program for Children and Teens at Risk, Jerusalem.

Carstensen, M.B. and Schmidt, V.A. (2016), 'Power through, over and in ideas: conceptualizing ideational power in discursive institutionalism', Journal of European Public Policy, 23, 3, 318-337.

Clarke, J. and Newman, J. (1997), The managerial state: power, politics and ideology in the remaking of social welfare. Sage Publications, London.

Clarke, J. and Newman, J. (2012), 'The alchemy of austerity', Critical Social Policy, 32, 3, 299-319.

Cohen, N. (2013), 'The power of expertise? Politician-bureaucrat interactions, national budget transparency and the Israeli health care policy', Policy Studies, 34, 5-6, 638-654.

Cox, R.H. (1998), 'The Consequences of Welfare Reform: How Conceptions of Social Rights are Changing', Journal of Social Policy, 27, 1, 1-16.

Dahlström, C. (2009), 'The Bureaucratic Politics of Welfare-State Crisis: Sweden in the 199os', Governance, 22, 2, 217-238.

Deakin, N. and Parry, R. (2000), The Treasury and social policy: The contest for control of welfare strategy. Palgrave Macmillan, London.

Dean, M. (2010), Governmentality: Power and rule in modern society. Sage, London.

Dolev, T. (2009), 'The National Program for Children and Teens at Risk: Background, Principles and Actions during the First Two Years of Implementation', Overview of Social Services 2009, The Ministry of Welfare, Jerusalem.

Eskelinen, T. and Sorsa, V. (2013), 'The Production of Institutional Facts in Economic Discourse', World Political Science, 9, 1, 1-30.

Evaluating the Conditions of Children and Teens at Risk and Distress (2006), Final Report, Jerusalem, The State of Israel.

Farnsworth, K. and Irving, Z. (Eds.) (2015), Social policy in times of austerity, Policy Press, Bristol.

Gal, J. and Ben-Arie, A. (1999), 'Poor Children in Israel: How to reduce this Phenomenon?', in Children in Israel at the verge of a new Millennium, edited by A. Ben-Arie and Y. Zionit. Jerusalem, Ashalim.

Hacker, J. S. (2004), 'Privatizing risk without privatizing the welfare state: The hidden politics of social policy retrenchment in the United States', American Political Science Review, 98, 2, 243-260. 
Haffert, L. and Mehrtens, P. (2015), 'From austerity to expansion? Consolidation, budget surpluses, and the decline of fiscal capacity', Politics \& Society, 43, 1, 119-148.

Harlock, J., Williams, I., Robert, G., Hall, K., Mannion, R. and Brearley, S. (2018), 'Doing more with less in health care: findings from a multi-method study of decommissioning in the English National Health Service', Journal of Social Policy, 47, 3, 543-564.

Heclo, H. and Wildavsky, A. (1974), The private government of public money: Community and policy inside British politics. The Macmillan Press, London.

Hirschman, D. and Berman, E.P. (2014), 'Do economists make policies? On the political effects of economics', Socio-Economic Review, 12, 4, 779-811.

Hoggett, P. (1996), 'New Modes of Control in the Public Service', Public Administration, 74, 1, 9-32.

Levy, J. D. (2010), 'Welfare Retrenchment', in F.G. Castles, S. Leibfried, J. Lewis, H. Obinger and C. Pierson (eds.), The Oxford Handbook of the Welfare State, New-York: Oxford University Press.

Lewis, J. and West, A. (2017), 'Early childhood education and care in England under austerity: continuity or change in political ideas, policy goals, availability, affordability and quality in a childcare market?', Journal of Social Policy, 46, 2, 331-348.

Mandelkern, R. (2015), 'What made economists so politically influential? Governance-related ideas and institutional entrepreneurship in the economic liberalisation of Israel and beyond', New Political Economy, 20, 6, 924-941.

Marier, P. (2005), 'Where did the bureaucrats go? Role and influence of the public bureaucracy in the Swedish and French pension reform debate', Governance, 18, 4, 521-544.

Ministry of Welfare and Brookdale-JDC (2007), Toward the Community - Evaluation Research. Jerusalem.

Morris, L. (2019), 'Reconfiguring Rights in Austerity Britain: Boundaries, Behaviours and Contestable Margins', Journal of Social Policy, 48, 2, 271-291.

Nachmias, D. and Klein, E. (1999), The Economic Arrangements Law: Between Economics and Politics, Israel Democracy Institute, Jerusalem, Position Paper No. 17.

National Insurance Institute (2003), The Effect of the Economic Plan on the National Insurance Institute, NII, Jerusalem.

National Program for Treating Children and Teens at Risk and Distress (2007), Project Book, The State of Israel.

National Program $\left(360^{\circ}\right)$ for Children and Teens at Risk (2015), Program Evaluation Report, The Center for Educational Technology, Tel-Aviv.

Newman, J. (2001), Modernizing Governance - New Labor, Policy and Society. Sage Publishers, London.

Newman, A.L. (2003), 'When opportunity knocks: Economic liberalisation and stealth welfare in the United States', Journal of Social Policy, 32, 2, 179-197.

Papadopoulos, T. and Roumpakis, A. (2018), 'Rattling Europe's ordoliberal 'iron cage': the contestation of austerity in Southern Europe', Critical Social Policy, 38, 3, 505-526.

Pierson, P. (1994), Dismantling the Welfare State?: Reagan, Thatcher, and the Politics of Retrenchment. Cambridge University Press.

Pierson, P. (2011), The Welfare State Over the very Long Run, ZeS Working Paper, Universität Bremen.

Roberts, A. (2011), The Logic of Discipline: Global Capitalism and the Architecture of Government. Oxford University Press, New-York.

Schmidt, V.A. (2008), 'Discursive institutionalism: The explanatory power of ideas and discourse', Annual Review of Political Science, 11, 303-326.

Schwartz, H. (1994), 'Small states in big trouble: State reorganization in Australia, Denmark, New Zealand, and Sweden in the 1980s', World Politics, 46, 4, 527-555.

Shalev, M., Gal, J. and Azary-Viesel, S. (2012), 'The Cost of Social Welfare: Israel in Comparative Perspective', in D. Ben-David (ed.), State of the Nation Report: Society, Economy and Policy in Israel 2011-2012, Jerusalem: Taub Center. 
Standring, A. (2018), 'Depoliticising austerity: narratives of the Portuguese debt crisis 2011-15', Policy \& Politics, 46, 1, 149-164.

Starke, P. (2006), 'The politics of welfare state retrenchment: A literature review', Social Policy \& Administration, 40, 1, 104-120.

Wanna, J., Jensen, L. and de Vries, J. (2010), The reality of budgetary reform in OECD nations: Trajectories and consequences. Edward Elgar Publishing.

Wildavsky, A. (1993), 'Budget Games are Ready for Reform', in K. A. Eliassen and J. Kooiman (eds.), Managing Public Organizations: Lessons from Contemporary European Experience, London: Sage. 